\title{
VIDEO OBSERVATIONS OF CULTURED BENTHIC FORAMINIFERA FROM THE MID-ATLANTIC CONTINENTAL MARGIN
}

CORLISS*, Bruce and BORNMALM, Lennart, Department of Geology, Duke University, Durham, NC 27708

Benthic foraminifera from a $220 \mathrm{~m}$ site on the Charleston Bump east of Charleston, $\mathrm{SC}$ were collected from box cores on a series of cruises and maintained at an ambient temperature of $12^{\circ} \mathrm{C}$ onboard ship. The samples were then transferred to an environmental room with temperature control and kept at ambient temperature and atmospheric pressure. The fauna was added to narrow "antfarm" aquaria and attached to a recirculating seawater system using Instant Ocean as the culture media. The cultures were fed two species of phytoplankton once or twice a week.

Dominant taxa from this continental margin site include Cibicidoides pachyderma, Uvigerina peregrina, Bulimina, Globobulimina and agglutinated taxa. Observations on the living taxa show that the fauna occupies both epifaunal and infaunal microhabitats. The formation of burrows by various taxa demonstrates that benthic foraminifera contribute to the bioturbation of deep-sea sediments.

Rates and patterns of movement of two species, Cibicidoides pachyderma and Ammodiscus incertus were documented in both antfarms and culture dishes. The rates of movement varied from 1.0 to $23 \mathrm{~mm} /$ day and are similar to rates of deepsea taxa, but slower than shallow-water species.

The presence of juvenile specimens of many taxa 5-6 months after collection of the material suggests that reproduction has occurred, since growth rates of both shallow and deep $(770 \mathrm{~m})$ taxa are on the order of a few months to reach adult size. Reproduction of Cibicidoides pachyderma has been confirmed in monospecific cultures during the last six months.

In this video presentation, observations on both epifaunal and infaunal taxa are made using a side-mounted dissecting microscope, a high resolution video camera and a time-lapse recorder. The observations document the mode of movement of both epifaunal and epifaunal taxa and the types of structures that are created as a result of their activity. 